ロファイルをそろえたことで, MUSCOT法とTCOT法の画像再構成 法の違いによる画質(面内分解能)を評価することが可能であった。

317 NEQを用いたMSCTにおける機種別画像特性一第 1 報 コ ンベンショナルスキャンー

大阪市立住吉市民病院・放射線科 寺川彰一, 泉谷信行, 山本安美 りんくう総合医療センタ一市立泉佐野病院・中央放射線部 中平修司 濱田有子

総合病院中津川|市民病院・診療部放射線技術科 原 孝則

【目的】検出器の形状および配列，画像再構成法の違いなど，各装置 ともさまざまに異なった特性を持っているため，同一条件下で撮像 することは不可能である，今回は各装置間で吸収線量を一定にした 条件の下, NEQの概念を導入し，機種別画像特性について比較検討 を行った。

【方法】使用装置として，Aquilion/M8(TOSHIBA), Lightspeed pro16 (GEMS)を使用した。 スキャン方式は，コンベンショナルスキャン とした，最初に，同一撮影条件下で撮影するため，線量特性につい て評価した. 次に, NEQ算出に必要な項目の測定方法として, コン トラストスケール (CS)の測定，MTFX-Yの測定拉よびウィナースペ クトル (WS)の測定を行い，これらはX線CT装置の性能評価に関す る基準(案)により規定された方法で行った. そして，NEQによる解 析は, NEQ $(u)=\operatorname{SNR}(\mathrm{u}) 2=(\log 10 \mathrm{e}) 2 \cdot \mathrm{CS} 2 \cdot \mathrm{MTF} 2 / \mathrm{WS} よ り$ 求め, マルチスライスCTシステムの撮影条件 (出力線量)におけるCT画像 が持つ信号検出能力を空間周波数的な要素として総合的に把握し， 機種別に比較検討した。

【結果】MTFはG装置が高く，WSはT装置が低い結果となり，NEQを 算出することにより機種別画像特性を比較することができた.

【結論】CTにおいてフィル夕関数やさまざまな条件によりMTFとWS は大きく変化するため，NEQを算出することにより機種別画像特性 の評価が可能であった。

\section{8 発表取り下げ}

319 造影CT検査における最適実効エネルギーに関する基礎的検 討 第 3 報 ビームハードニング効果による線質変化の検討 国立大学法人北海道大学病院・診療支援部山下道明, 笹木工 石坂欣也, 孫田惠一

\section{石狩幸惺会病院 山下明美}

【目的】第60回総会においてX線CTのファンビーム内における実効エ ネルギーの変化について報告を行った．今回はビームハードニング 効果が線質に与える影響について検討することを目的とする.

【方法】東芝メディカル社製Aquilion multi (4DAS)を使用した。中心部 に樹脂製のロッドを設置したファントムをスキャンした。ファント ム径とロッドの材質を変化させ, 組み合わせてスキャンを行った。 得られた画像のロッド部分のCT值を計測した.ロッドの線減弱係数 と実効エネルギーの関係と計測結果を比較することによってファン トム中心における線質の変化を検討した.

【結果・考察】各ロッドのCT值は，ファントム径によって変化した。 変化量と変化傾向はロッドの材質により異なった。今回実測した ファントム径とCT值の関係は, ロッドの線減弱係数と実効エネル ギーの関係と同様の傾向が見られた，ロッドの材質が変わっても両 者の関係には同様の傾向が見られた。この結果からロッドのCT値を 計測することによって，径の異なるファントム中心部における，実 質的な実効エネルギーの変化を推定できるものと考えた.
320 ピッチの違いによるヘリカルアーチファクトの解析一周波数 解析一

福井大学医学部附属病院·放射線部 石田智一, 山口 功 木戸屋栄次, 渋谷 翼

シーメンス旭メディテック(株) · MSM-CT 伊藤俊英

【目的】CT画像はMSCTの登場により，高精細化が実現された。しか しCT画像には，さまざまなアーチファクトが含まれている，特にへ リカルスキャンを行った場合, 体軸方向の収集データ乗換えによ り,ヘリカルアーチファクトが発生し, 選択するへリカルピッチの 違いによってアーチファクトに変化が生じる，現在アーチファクト の評価は，2 值化やsubtraction処理による方法が発表されているが, 闒值の設定やX線照射位置, 寝台位置の違いにより問題点も含まれ ている. 今回我々は, 定量的評価法の確立を実現を目的とし, 周波 数解析を用いたピッチの違いによるへリカルアーチファクト成分の 変化を解析したので報告する。

【使用機器, 方法】CT装置 : SIEMENS SOMATOM sensation 16 ファ ントム：アクリル製球体(直径 $5 \mathrm{~cm}$ ) 周波数解析：MATLAB 自作 解析プログラム ファントムを各へリカルピッチ(0.5-1.5)にてス キャンをした，得られたCT画像のファントム周辺に発生している アーチファクトを抽出し，そのデータをフーリエ変換しアーチファ クトの成分を解析した.

【結果】ヘリカルピッチの違いによって周波数プロファイルが変化 し，ヘリカルピッチが大きくなるにつれて高周波成分が多くなる傾 向になった、ヘリカルピッチの違いによって周波数プロファイルの 曲線下面積が変化してアーチファクトの比較が容易にできた。

【考察】周波数プロファイルの曲線下面積を求めることで臨床におけ るへリカルピッチの設定の指標として有効であることが示唆され た，今回評価したアーチファクトは，ヘリカルアーチファクト以外 のアーチファクトも含むと考えられる. 今後は, axial画像の評価だ けではなく体軸方向の評価へと適用させていきたい。

321 Scoring評価法による低線量CTスキャン条件選定の試み 浜松PET検診センター 小室裕冉，竹内美穂，中村明弘，伊東 繁 佐野由高, 岡田裕之, 犬伏正幸

【目的】我々の施設ではPET検診の補助検査として胸部一上腹部低線 量CTスキャンを行っている。低線量スキャンには検出サイズ, 検出 コントラスト等の検出目的の明確化と同時にこれを踏まえた装置固 有の描出能把握が必須である. 今回我々はサイズ，コントラストが 既知のファントムを用い様々なX線量による一連のスキャンをもと に，低線量CTスキャン条件設定のための新しい描出能評価 (Scoring 評価)を行った。

【方法】実験に用いた機器, 手法は以下の通りである。(1)CT装置： GE社製Light Speed Ultra (8DAS) スキャンはAxial Scan, 80〜140KV, 20 400mA (20mA毎), Slice厚 5mm, (2)ファントム：Catphane CTP 515低コントラストモジュール 上記条件下の全80スライス画像を WL：ターゲット平均CT值, WW : 100 (統一) で半切一枚20画像の フィルムとして出力し, 画像毎に切断, 混成化した. シャーカステ ン上12名の観察者が描出能を視覚的に10段階で判定した。また夕ー ゲットCT值の統計処理から各画像のSD値 (Noise Index)を求めた.

【結果・考察】コントラスト毎に分離した, X線量一画像SD值一検出 サイズの相関関係が導かれた．本法は低線量CT適正スキャン条件を 得るために有用と考えられる。

\section{6 列MSCTにおける右冠動脈の抽出能の検討} 函館五稜郭病院-放射線科 仁科朋美，木下 淳, 小山内幸次 能渡竜洋

【目的】心電同期再構成法に抢いて冠動脈を観察するための最適な収 集phaseは拡張周期であることが知られている。しかし拡張周期の最 
適心位相でVR画像を作成した場合, 左冠動脈 (LAD/LCX)に比べ右 冠動脈 (RCA)の抽出能が劣るVR画像が作成される症例もある. そこ で今回，心位相の違いによるRCAの抽出能の検討を行ったので報告 する.

【使用機器】CT装置 : 東芝社製Aquillion16 (Super Heart), ワークス テーション：アミン社製ZIO M900 QUADRA

【方法】スキャン条件の自動設定ソフト「ハートナビ」で得られたデー 夕に対し拡張周期であるR-R間隔 $65 ， 70 ， 75 ， 80 \%$ で再構成した axial画像から最適心位相を決定し, VR画像を作成する。一方収縮周 期であるR-R間隔 $30 ， 35 ， 40 ， 45 \%$ で再構成したaxial画像からRCA が一番良く抽出されている心位相を決定し，VR画像を作成する。作 成したRCAのVR画像にて, \#1〜\#4 までアーチファクトが少ない画 像を優, アーチファクトが目立つが読影可能な画像を良, 抽出不良 を否とし，各々のVR画像を視覚評価した。

【結果】1)RCAのVR画像は，拡張周期に扔いて優が60\%を占めたのに 対し, 取縮周期では $30 \%$ あった. 2)患者別においては約 7 割が拡 張周期の評価が良かった．3）拡張周期で抽出不良でも収縮周期を再 構成することによって，良レベルのVR画像が得られた．

【考察】拡張周期での最適心位相の方が収縮周期に比べ優位であった が，RCAの抽出能を高めるためには収縮周期での心位相のVR画像も 作成し，比較検討する必要がある，スキャン中，一定の心拍数が得 られない場合, 左冠動脈に比べ右冠動脈のBandingアーチファクトが 目立つため, $\beta$-ブロッカーの投与を考えなければならない.

$3232 \mathrm{D}$ および $3 \mathrm{D}$ 画像を用いた最適心位相選択における視営的 評価の妥当性に関する検討

JA広島総合病院· 中央放射線室 山口裕之, 山路 周, 砂田研二 大和真一郎

JA広島総合病院・画像診断部 藤川光一

【目的】冠動脈CTAGでは, 種々のアーチファクトの影響を避けるた め, 任意のaxial画像あるいは試験的に作成した3D画像を視覚的に評 価し, 冠状動脈の観察に最適な心位相を選択する方法が用いられる (それぞれ2D法，3D法とする)。今回はこれら視覚的評価の妥当性に つき，2003年 6 月19日〜2003年10月 6 日の期間に冠動脈CTAGを実 施した27症例を対象に検討した。

【方法】各症例につきRR間隔 $0 \%$ から $95 \%$ まで $5 \%$ 間隔で得た $20 心$ 位 相の3D画像を対象に, RCAとLADについて4段階のスコアリングを 行い, 最高得点の心位相およびその心位相の得点と有意差のない心 位相を最適心位相群とし，これを以下の検討のgold standardとした. 判定者は循環器内科医師 2 名, 画像診断部医師 2 名, 診療放射線技 師 6 名の計10名である．評価は，各症例につき上記10名が全心位相 のaxial画像および3D画像のRCAとLADを観察し, 各人が最適とし て選んだ心位相が前述の最適心位相群に含まれている率(合致率)を 求めることで行った。 なお2D法にはRCA\#2 の中央レベルの画像を 用いた。

【結果】最適心位相群との合致率は2D法ではRCAで $83 \%$, LADで $80 \%$ であったのに対し，3D法ではRCAで100\%，LADで96\%であった。 【結論】2D法では最適な心位相を選択することができない場合が約 20 \%あるが，3D法では合致率はほぼ100\%であり，最適心位相の選択 には3D法の方が有効である.

$324 \mathrm{MDCT}$ 用いた心電図再構成における心拍位相の検討 榊原記念病院·放射線科堀江賢二, 伊山 篤, 飯山利健, 坂尾武彦 【目的】心電同期再構成に扔いて, 動きの少ない心時相での画像を作 成することは診断の上でとても重要である。しかし心拍数の変動に より位相の決定が難しい場合がある，そこで今回心拍数の変動時に おける位相決定について検討した。

【使用装置】SIEMENS社製：SOMATOM Sensation16
【万法】位相を決定する 4 方法 (1. 相対遅延法 2. 絶対遅延法 3 . 絶対戻し法 4. 任意)ごとにVR画像を作成する．各画像を視覚的に 評価し，最適な位相が得られる方法を検討する。

【結果】心拍数の変動があるとP-R時間, R-T時間に差が生じる。心拍 数の変動がない時では相対遅延法. 絶対遅延法での位相変化は大き く見られなかったが，P-R時間に差がなくR-T時間に差が生じる場合 には絶対遅延法が有用であり，P-R時間に差が生じR-T時間に差がな い場合には絶対戻し法が有用であった，P-R時間，R-T時間共に差が 生じる時は任意で位相を決定する方法が有用であった。

【結語】今回の検討により，位相を決定する際には心電図のP.R.T波の 位置関係が重要であり，波形によっての使い分けが必要と思われ る。

325 Retrospective再構成法における至適心時相の定量的評価の 試み 兵庫医科大学病院 - 中央放射線部 井上裕之, 田ノ岡征雄、名定敏也 兵庫医科大学病院 - 中央医療画像部門 平山伸一，琴浦規子

【目的】Retrospective再構成法を用いた心臟CT検査において, 至適心 時相の決定は，複数の心時相を再構成したAxial画像が用いられるこ とが多い。しかし，Axial画像を用いた心時相の判定は視覚評価によ るところが大きいために，実際の至適心時相とは多少のずれが生じ る場合がある. また, 至適心時相の候補が複数ある場合, その判定 はAxial画像のみでは困難となる。そこで我々は, Axial画像を用いて 周波数解析を行うことにより，至適心時相の定量的評価を試みた。 【方法】Retrospective再構成法により得られたデー夕を基に，心時相を 0から $95 \%$ まで $5 \%$ おきにAxial画像を再構成した，RCA起始部， RCA(\#2), LAD起始部レベルのAxial画像について, 血管に関心領域 を設定し, 周波数解析を行った。 また, 従来法である視覚評価によ る方法と比較検討した。なお，CT装置はSIEMENS社製SOMATOM Sensation Cardiacを使用し, 周波数解析は自作プログラムを用いて 行った。

【結果】周波数解析では, 静止時, 拍動時に一致して周波数の変動が 見られ，拍動時には低周波成分が大きくなる傾向があった。この結 果, 関心領域を設定したそれぞれの部位に適した至適心時相を決定 することができた。

【結論】周波数解析より, 静止時と拍動時の周波数分布の変化を捉え ることができ，至適心時相の定量化の可能性が示唆された．今回は 血管起始部レベルについての検討を行ったが，末梢レベルについて も応用が可能であると考える. 現在, 至適心時相の決定には視覚評 価によるところが大きいため, 定量的な評価が行える点で本法は臨 床的に有用と思われる。

326 心拍同期画像再構成法における位相時間分解能とアーチファ クトの関係

藤田保健衛生大学・衛生学部 秋野成臣, 辻岡勝美, 岩田 学 内田守彦，植林義統

藤田保健衛生大学病院 井田義宏

市立四日市病院 高橋康方

【目的】我々はマルチスライスCTによる心拍同期画像再構成法の新し い評価指標として位相時間分解能を提案している. 位相時間分解能 とは一心拍の時間における時間分解能の割合を意味する。同じ時間 分解能でも心拍数が高ければ一心拍中に占める時間分解能の割合は 多くなり，逆に心拍数が低い場合は一心拍中に占める時間分解能の 割合は小さくなる。つまり同じ時間分解能でもモーションアーチ ファクトの発生が異なってくると考えられる，今回我々は位相時間 分解能とアーチファクトの関係について検討を行った。

【方法】実験には東芝社軗Aquilion16を用いた。時間分解能とアーチ ファクトの測定には自作のムービングファントムを用いた。この 